Journal of the Scholarship of Teaching and Learning, Vol. 21, No. 4, December 2021, pp. 56-68. doi: 10.14434/josotl.v21i4.32708

\title{
Teaching Social Justice and Engaging Gen-Z Students in Digital Classrooms During COVID-19
}

\author{
Aisha Powell, Kapriatta Jenkins, Britney Gulledge, and Wei Sun \\ Howard University
}

\begin{abstract}
The outbreak of COVID-19 in 2020 dismupted the lives of people on all fronts, but especially the traditional education system. Now dependent on online learning during a global pandemic, political unrest, and a contentious presidential election, many school educators were forced to transition to virtual instruction amid the ongoing health crises posed by COVID-19 and the everpresent issue of racism. We gathered and analyzed the teaching experiences of instructors at an historically Black college or university as they addressed social justice issues during the COVID-19 pandemic. The majority of college-age students today are from Generation Z (Gen Z), the "digital native" generation. They are living in a time in which recent social justice movements have called them to the frontlines. To teach Gen-Z students, faculty should create courses that fit their needs and consider innovative teaching strategies to engage them in classrooms. We discuss three classroom activities that showcase instructors' pedagogical efforts during such unprecedented times.
\end{abstract}

Keywords: social justice, critical pedagogy HBCU, Black Lives Matter (BLM), COVID-19, misinformation, public narrative.

The outbreak of COVID-19 in 2020 disrupted the lives of people on all fronts. Within the education system, the pandemic forced schools and universities to transition to online learning amid concerns that the classroom could be a contagious environment in which the virus could spread. Yet even during this global pandemic, racial injustice continued to be the biggest threat to public health, one that many people of color have been facing for centuries. Amid the pandemic, political unrest played out through the Black Lives Matter (BLM) movement and a controversial presidential election. The current social and political environment has made it imperative that students need to be equipped with critical thinking skills to properly understand the world around them and help them in their decision making.

As Freire $(1970 ; 1998)$ articulated, critical pedagogy is a praxis in which students question and challenge dominant understandings of society to achieve critical consciousness. Furthermore, it also flips the traditional classroom structure, such that the teacher also becomes a student, and the student becomes a teacher. Coupling this praxis with an online model of teaching can create a digital classroom that is both a tool for critically understanding the status of society and an environment that meets the needs of the digital-savvy Generation Z (Gen Z).

Gen Z, or individuals born after the year 2000 from ages 18 to 21, are generally characterized as open-minded, highly motivated, thoughtful, and responsible (Seemiller \& Smith, 2019). These socalled digital natives are living in a time where a plethora of information, about activism efforts and social justice issues, is easily accessible. Studies have shown that members of Gen Z like using social media to make a difference, have progressive dialogues about issues, and learn about different social movements (Harris, 2019; Seemiller et al., 2019), such as the Black Lives Matter (BLM) movement. They are also living in a time where social justice movements have called the youth to the frontlines as vocal activists and key players in shaping the future. The news media has also played a large role in framing the events of physical protests, sometimes painting an alternative narrative that conceals the violence instigated by law enforcement and instead portrays civilians as aggressors (Dessem, 2020; 
Jackson, 2020; Kilgo, 2020; Pierre-Louis, 2020). In addition, the internet has become a central tool for spreading pertinent health content during the COVID-19 pandemic; however, it has also become a tool for spreading misinformation at the same viral rate (Bode \& Vraga, 2017; Chou et al., 2018; Moorhead et al., 2013; Yeung, 2018).

Teachers in $\mathrm{K}-12$ and higher education have been experimenting with teaching social justice in the classroom to help students become more aware of racism and how to take action to work toward solving social problems of concern to individuals, schools, and communities (Howell et al., 2019; Reyes \& Sander, 2019). Particularly during the COVID-19 pandemic, social justice and social issues have intersected, and students have been challenged with adversities relating to their overall health, as well as difficulty transitioning to a more self-sufficient independent learning style (Huchting \& Stephenson, 2021; Kelly, 2021). For educators, this means adapting the traditional classroom and crafting courses that fit the generation's unique digital and social needs, while implementing innovative teaching strategies to engage them in the classroom. During this critical time of multilayered unrest, three areas-social justice, COVID-19 misinformation, and Gen Z learning style-have been identified for educators to address.

We explored and analyzed the actual teaching experience of addressing social justice issues during the COVID-19 pandemic in three digital classrooms at an HBCU (historically Black college and university). HBCUs are central environments where students can critically engage in social justice actions. This is because their students come from the core populace of individuals deeply affected by the social, political, and economic oppressions caused by White supremacy and racism. Using the model of activity-based learning, as articulated by Pang (2010), each educator utilized online activities to accommodate for the difficulties caused by the COVID-19 pandemic and engage students in critical thinking. We use a reflective essay style to discuss three critical pedagogical teaching activities: guiding students in tracking down misinformation related to COVID-19 and BLM; using community leader/celebrity speeches to inspire; and using public narrative for critical engagement in social action.

\section{Literature Review}

This section reviews the existing literature on the importance of critical media literacy for assessing information and misinformation online, the use of role models for effective learning, and the utilization of public narratives to inspire civic participation and social action. Each part of this section can be seen as a guide to an activity that is detailed later in this article.

\section{Critical Media Literacy}

The act of engaging in critical media literacy is roughly described as understanding how power structures in society shape and frame media representations and how audiences interpret them (Forsman, 2020; Kellner \& Share, 2007). In the age of "fake news" and heightened media manipulation, media literacy education has been focused on empowering audiences to evaluate media content by questioning its authenticity, framing, and meaning-looking beyond what they see on the surface (Alvermann et al., 2017; Hobbs, 2012; Kellner \& Share, 2005, 2007). Critical media literacy theorists use lenses of semiotics, multiculturalism, feminism, and postmodernism to analyze media as forces that reproduce dominant ideologies; this strategy enables the possibility of counter-hegemonic options (Garcia et al., 2013; Kellner, 1995). Scholars and educators have used this framework to explore how for-profit media operate in their own economic and political interests (Torres \& Mercado, 2006), to facilitate peer conversations and explorations about representations in media texts (Gainer, 2010), and to counteract the narratives of the most privileged dominant group (Funk et al., 2016). The

Journal of the Scholarship of Teaching and Learning, Vol. 21, No. 4, December 2021. josotl.indiana.edu 
traits that are elicited from critical media literacy are especially important when navigating in the online environment through the waves of information and misinformation during the COVID-19 pandemic.

\section{Critical Media Literacy, COVID-19, and BLM}

COVID-19 has transformed the media environment of modern society on two specific frontshealth-related news and coverage of anti-police brutality protests-and it has illuminated how misinformation online can be detrimental to the public. While online-mediated communication has helped inform the public, it has also been used as a tool to spread myths. For instance, in February 2020, multiple news reports from international media reported that Black people were immune to COVID-19 because of their "blood genetic composition," "black skin," and antibodies that are " 3 times stronger, [and more] powerful and resistant compared to that of white [sic]" (City Scrollz, 2020, para 5; Natty 2020). Falsehoods during health crises are not uncommon (Fung et al., 2016; Moran; 2020), and myths surrounding Black and African American resistance to deadly diseases have been around since slavery (Espinosa, 2014; Hogarth, 2019; Oyeymi et al., 2014). The COVID-19-related myth, however, came at a time when staggering numbers of African Americans were dying from the virus at disproportionate rates. Although a litany of news outlets combatted the specific Black immunity myths regarding COVID-19 (J.N. Golden, 2020; S.H. Golden 2020; Maqbool, 2020; Ross, 2020), the myth had already bolstered the overall apprehension and resistance of Black individuals to getting tested for COVID, getting vaccinated, and trusting Western medicine (Maqbool, 2020; McLernon, 2021).

At the same time, the internet has also been a playground for media outlets and the public to inform and discuss public happenings, such as the demonstrations that occurred during the BLM and George Floyd protests. Traditionally, the news media has been instrumental in relaying information about protests and providing their context, such as why they are happening and who is protesting (Happer \& Philo, 2013). Subsequently, it can shape public opinion on events in an agenda-setting fashion by the way the news is presented (Nelson \& Oxley, 1999). The media's framing of racially motivated attacks - including the terminology used, the indication of who the agitator is, and coverage of the consequent mass outrage-has been shown to skew public perceptions in one direction or the other (Dukes \& Gaither, 2017; Fridkin et al., 2017). Particularly when the frames correspond to existing stereotypes of a presupposed aggressive Black person and docile White victims (Juris, 2005; Watkins, 2005), the media can effectively reinforce social stigma against marginalized groups.

The classroom can be utilized to cultivate a keen awareness of misinformation and empower future generations to be critical of information in the media (Frechette, 2002; O'Byrne, 2013). The online teaching environment that COVID-19 has ushered in can thus serve as a powerful tool to cultivate critical media literacy among members of Gen Z. It can be used to explore how the media portrays and circulates both health and racial news pertaining to the most vulnerable groups.

\section{Role Models and Effective Learning}

Researchers have examined the use of role models in a variety of educational fields. Jack et al. (2017) studied the use of role models in undergraduate nursing education and its effect on personal and professional development. Results revealed that students valued positive role models and viewed them as beneficial to their learning. Baden (2014) explored how positive and negative role models affect business students' attitudes relating to their future business behavior. Results showed that positive role models offset the negative consequences arising from negative role models. Positive role models showed that business could be ethical and profitable, leading to increased intentions to engage in ethical business behavior.

Journal of the Scholarship of Teaching and Learning, Vol. 21, No. 4, December 2021. josotl.indiana.edu 
As our study focuses on the HBCU environment, it is important to understand how role models can impact minority students. Karunanayake and Nauta (2011) examined whether race was a determining factor in college students' identified career role models, the number of identified career role models, and their perceived influence from those models. They found that students were likely to have role models whose race was the same as their own.

The use of role models in the classroom has been shown to result in positive reactions in students and even encourages them to be more successful in their future careers. Students may be even more encouraged to succeed when they see role models who share their race in their future career fields. Using role models can help serve as a positive example and increase attentiveness in education.

\section{Public Narratives, Civic Participation, and Social Action}

To engage and support Gen- $Z$ students as they navigate undergraduate studies and a pandemic, the instructor should create a more supportive and reflexive learning environment. For public speaking, this includes creating physical and mental spaces for students to get involved in social movements and in lending their voices to campaigns, such as BLM, that arose during the pandemic. Furthermore, through critical media literacy, one can engage in and dissect popular culture and media to make room for counter-hegemonic possibilities (Kellner, 1995).

Storytelling and personal narrative are imperative for sharing and organizing within and outside the classroom (Ganz \& McKenna, 2018). Using Ganz's public narrative model from the theory of change, an instructor could help students situate themselves in the social issues they want to help alleviate. Public narrative is the art of translating values into emotional resources for action. It is a discursive process through which individuals, communities, and nations learn to make choices, construct identity, and inspire actions. Public narrative engages the "head" and the "heart," so it can instruct and inspire-it not only teaches people why they should act but also motivates them to act (Ganz \& McKenna, 2018). Public narrative is a leadership practice of using personal values to galvanize others into action through storytelling (Ganz, 2010). As students are supported in their exploration of social issues that they would like to lend their voices to, they accept the challenge and responsibility involved in helping others achieve their purpose in a time of uncertainty. Narrative and stories are used to show how personal decisions are made on the basis of values and the construct of self. At the group or community level, people who have shared similar experiences and values can unite to take action (Ganz, 2010).

The focus of a public narrative in the Principles of Speech class is to strengthen a student's capacity for leadership. Students develop a "story of self" (why I have been called to lead), a "story of us" (why we have been called to act), and a "story of now" (why we have been called to act now). There is extensive research on why storytelling and narratives are imperative in education and teaching pedagogies (e.g., Coulter et al., 2007; Phillips, 2013). Researchers believe that stories help people shape identity, make meaning of life, and eventually motivate themselves for action. Moreover, narratives can activate emotional engagement in learning (Byrnes, 2001; Camfield et al., 2020; Hardcastle, 2003). As defined by Ganz (2010), the public narrative model builds on the importance of storytelling by connecting the individual stories to the larger story of the community. The model focuses on engaging challenge and choice of the speaker that can elicit emotion and connection to the audience (Ganz, 2010).

\section{Teaching Social Justice Through Classroom Activities at an HBCU}

The first three authors of this essay are doctoral students who are basic course instructors at an HBCU. Their pedagogical experiences addressing social justice issues during the pandemic are presented here.

Journal of the Scholarship of Teaching and Learning, Vol. 21, No. 4, December 2021. josotl.indiana.edu 


\section{Activity-Based Learning for Social Justice (Instructor P)}

During a fall 2020 speech class at an HBCU, 72 undergraduates did an activity involving finding and disproving misinformation. The activity was designed to encourage students to use critical media literacy techniques in their discovery and subsequent discussions. This activity used the basic premise of the Pang (2010) activity model for fostering active learning by challenging the traditional classroom norm. Pang's (2010) model uses activities to create a more stimulating experience, where retention of the material is based on exploration and experimentation. Many educators have seen the success of Pang's idea of activity-based learning in their classrooms, with increased test scores, improvement in reaching learning objectives, and overall interest in the course matter increasing (Bassett et al., 2014; Hussain et al., 2001; Savage et al., 2009).

The first part of the activity was a Wikipedia search, where students were asked to go on Wikipedia and identify bias information on pages. Wikipedia has an organized page where articles that have been flagged for using "peacock" terms (language that bolsters the importance of a person or thing without any facts to back it up) are listed (Wikipedia, n.d.). Students were asked to evaluate four articles of their choice for peacock language and to write a short reflection on the assignment. This reflection included why they chose each article, what the peacock term or misleading information in the article was, and how this information can slight a reader. Wikipedia is the most used public, nonprofit platform for individuals to get quick information on almost any topic. However, due to its open access, information can be altered at any given moment. After the reflection, students were directed to present their specific findings and how the framing of the article reflected bias in overt and subtle ways.

The following week students were given a follow-up assignment to find misleading information regarding the George Floyd protests or about COVID-19. As with the Wikipedia activity, students were instructed to assess four articles relating to a protest and/or COVID-19 and to search for the same peacock terminology or other misleading presentations of facts. For this assignment, students worked in groups of four to five and were asked to synthesize their findings to make a generalization about the news media and how they use it. Overwhelmingly, students were shocked to find that the same peacock terms that appeared in obscure Wikipedia pages were also reflected in the news stories by large media institutions.

Furthermore, students found that unsubstantiated claims and half factual statements were especially prevalent in coverage of the protests. Each group presented their findings to the class and together the class engaged in a larger conversation about the uses and misuses of the internet in times of heightened tensions. This activity helped students identify and deconstruct misinformation, in both health- and race-related media. It also helped them engage in critical media literacy not only on an individual level but as a collective, where they were able to articulate and discuss media bias and how it can be harmful.

COVID-19 and the George Floyd protests are two contemporary phenomena where falsehoods were known to be spread, but this type of activity can be applied to any type of event, and especially those that impact marginalized groups. To stimulate future generations' inclination to engage with social justice issues, activities such as this can be utilized to spark general interest, combat falsehoods through investigation and discussion, and cultivate a new class of learners who are more critical about what they think they know.

A reflection-based survey was given to students to assess their feedback on the activity. Fortysix students responded and their reactions were overwhelmingly positive. Some of the highlights were the following: Of the 46 students, 41 felt that the prompt gave them just enough guidance while giving them some room to make autonomous decisions; 40 felt that the assignment made them think creatively on how to present information to the class; 44 reported that the assignment helped them

Journal of the Scholarship of Teaching and Learning, Vol. 21, No. 4, December 2021. josotl.indiana.edu 
critically engage with information; and 45 students found the activity applicable to understanding information and everyday life. For the group section of the activity, 38 of the 46 students rated their overall group experience as more favorable than doing the activity alone, 30 thought that working in a group helped them make progress toward being a more confident speaker in general, and 37 students said they would recommend this type of assignment for future speech classes.

Notable feedback from students included the following:

I enjoyed working with my group members. The best part of the assignment was that I was able to do the work on my time and the information was straightforward. It helped me communicate informally with my peers as well as communicate the material effectively.

It is like you know there's a lot of false information out there, but when you see for yourself in newspapers and online, it shows you that you really cannot trust anything. This assignment has made me more skeptical about what I consume.

\section{Assignment to Engage Gen-Z Students (Instructor J)}

A class assignment to help gauge students' interest in social justice and their understanding of public speaking styles was given to two separate Principles of Speech courses. In total, 64 students participated. Students were first asked to watch Representative John Lewis's "March on Washington" speech, in which he called for legislation that gave equal and fair treatment to Black Americans. Students were then asked three questions inspired by the lessons taught from the required textbook (Gunn, 2018): How did Rep. Lewis appeal to needs and emotions? Did Rep. Lewis use any examples in the speech that captured your attention? Is this speech relevant to today, and why or why not?

Students were then asked to watch a celebratory speech by Denzel Washington encouraging graduating seniors as they start their work careers. They were then asked another three questions: The speeches were meant to inspire. Recall the tips for celebratory inspirational speaking. Did Denzel use any of these? How did Denzel appeal to his audience? Is this speech relevant to you, and why or why not?

There were positive responses to both videos. Students analyzed the speeches and found ways in which the speakers connected to their audiences. When responding to how Representative Lewis appealed to needs and emotions, one student wrote: "He uses 'we' to create togetherness talking about what the Black community needs including himself and showing that the problem is as much as his problem as his audience."

Students also shared parts of Representative Lewis's speech that stood out to them. Many students noticed Lewis's effort to acknowledge the lack of support from government officials. One student stated:

One particular example of the desired leader that Representative Lewis alluded to in his speech that stood out to me was when he said we salute leaders that exploit but "what political leader can stand up and say, 'My party is the party of principles?' He alludes to the party of Kennedy and the party of politician James Eastland who viewed Black people as inferior. In providing this example of a unit existing to uphold white supremacy, Rep. Lewis urges and demands fair representation for black people.

Numerous students found the speech to be relevant to them and even gave reference to BLM. One student responded:

Journal of the Scholarship of Teaching and Learning, Vol. 21, No. 4, December 2021. josotl.indiana.edu 
Lewis's speech is relevant today because protestors still experience police brutality without protection under the law. Last summer, so many participants in the Black Lives Matter protests fell victim to excess force, irreversible injuries due to rubber bullets, and tear gas bombs.

Students found connections between Representative John Lewis's speech and experiences of African Americans today. With social justice efforts including protests being seen frequently through media, this assignment helped students make connections between what they had learned in class, their personal experiences, and the experiences of activists and public speakers.

Denzel Washington's speech encourages youth as they enter the world as adults. Students analyzed how Washington was able to use his own experiences to connect to the audience. One student stated:

Denzel used humor and vulnerability to appeal to the audience. He would lighten the mood and break the seriousness by making a joke about youth experiences. Denzel showed vulnerability by sharing his stories of fail and conquer, creating a connection between his audience and himself. This allowed the audience to relate to the speaker with shared experiences of failure.

Students were also able to make connections between what they learned in class and the techniques used by Washington. A student stated:

For instance, he repeatedly advised his audience to "fall forward." In making this statement he was advising his listeners to not fear failure and continue to work towards their goals until they succeed. He also involved a little comedy in his speech. This allowed him to connect to his audience and helped them view him as a friend. I also found that this made the speech more engaging and prevented the audience from getting bored.

When asked how the speech was relevant to them, students found the speech encouraging as they were striving for success. One student responded: “This speech is very relevant to me as a young woman in college, striving for big goals. I honestly think this is relevant to everyone because everyone could use some encouragement to persevere from an inspirational and successful person."

This assignment allowed students to see and hear examples of speeches by social justice activists and community leaders. Because many Gen-Z students like to learn by watching, they were able to take notes of the speaking styles used in the videos and apply them to their own speeches given in class. In addition to learning by example, they were also challenged to critically examine social justice issues experienced today and consider how they are relevant to them. They were also encouraged to think about their personal success and what paths they want to take for their future.

After this assignment, students thought of topics for their persuasive speeches. In connection with what they learned from Representative John Lewis's speech, topics chosen by students included activist efforts such as stopping police brutality, eliminating food deserts, and explaining the racial implications of high incarceration rates of African American men. In connection with Denzel Washington's speech, other students explored topics to help their fellow classmates succeed in their college careers, such as note-taking and organizing strategies. The assignments helped students understand how they can apply learning strategies to their personal lives.

Journal of the Scholarship of Teaching and Learning, Vol. 21, No. 4, December 2021. josotl.indiana.edu 


\section{Public Narrative as a Reflexive Model (Instructor G)}

Growing up in an era of many lauded and famed youth community organizers, Gen-Z students are familiar with peers using their voices to raise awareness of or to help alleviate local, national, and global crises_-such as Greta Thunberg, Little Miss Flint, and Malala Yousafzai. Many Gen-Z students have perceived injustice in relation to the environment, racial- and gender-based conflicts, and structural inequities. The racial inequalities in the COVID-19 pandemic have quickly become one of many preexisting social ills. Students have used community organizing as a form of social change in the online social movement (Welton \& Freelon, 2018).

This introductory communication course has a section focused on speaking for social change, in which the public narrative model is introduced. Research has shown that Gen- $Z$ students are most motivated by advocating for something they believe in and working toward advancement (Seemiller \& Grace, 2016; Working Narratives, n.d.), which often results in positive engagement with the social change assignments. For this assignment, students worked individually and in groups to create their individual public narrative based on a social movement that resonates with their interests. As a class, students watch four public narrative videos that provide examples of social movements and political speeches that engage the key identifying characteristics of a public narrative. These speeches include Barack Obama's 2004 Democratic National Convention speech, James Croft's 2012 Anti-Bullying speech at Harvard University, Malala Yousafzai's 2013 speech at the United Nations, and Greta Thunberg's 2019 speech at the United Nations Climate Action Summit. This mix of examples is intentional to introduce different topics and social issues to which this model can be applied as well as to introduce a variety of symbols, tones, and gestures that elicit emotions from an audience.

After the students collectively identify the pieces of public narrative in each speech, they are asked to model the same behavior for a social issue of their choosing. They receive a worksheet that outlines the "story of self," "story of us," and "story of now" to assist in guiding their process. Each student spends time outlining their stories, focusing on bringing in a personal anecdote that can broaden the focus to the community they want to reach. After completing this portion of the assignment on their own, they return to their group to share and receive feedback on which parts of their stories were vivid and emotional and which parts could be more substantial. Students polish their speeches based on their peer-to-peer feedback and present for the class. Students must complete a self-critique where they share reflections on their experience with the assignment in its totality, that is, what they did well, improvements, lasting impressions. Researchers have suggested that Gen- $Z$ students were empowered to engage in self-directed and peer learning and subsequently developed a preference for it (Seemiller \& Grace 2017), which helps explain the integration of the public narrative and personal interests.

Following are snippets of some of the feedback shared about using the public narrative model and how this assignment integrated with their overall social issue. The feedback from the assignment indicates that students were able to connect real-world issues in a reflexive model to locate themselves within the current social movement climate. One student wrote: "I tried to emulate tactics I saw from our examples by establishing a strong bond with my audience through sharing something near and dear to my heart." Another wrote:

I chose to talk about unsheltered people because right now, in the pandemic, I think they are people that get overlooked. It was vulnerable to share, but it brought up a good discussion with my group ... something I've experienced with having to move and not knowing where I would end up.

Journal of the Scholarship of Teaching and Learning, Vol. 21, No. 4, December 2021. josotl.indiana.edu 
Students were able to critically dissect the influential facets of media that appeal to emotions and logic. One student's self-critique mentioned: "I appealed to the audience's logic and emotion by asking them moral questions throughout the speech... I also appealed to the emotions of the audience by speaking from a position of inferiority to connect with the masses."

As students approach their personal public narratives, they are actively engaged in counteracting the narratives of the dominant group and creating space for new power dynamics in the world around them (Funk et al., 2016; Kellner, 1995). As a student stated: "I want this speech to be a symbol or a turning point against silence towards abuse and is in favor of speaking up against people, no matter how important they are, when they are wrong." Public narratives can not only help students ease into shared critical thinking but also resonate deeply with the oral history practices embedded in minority cultural practices, particularly within the Black community. Using this in an online setting emboldens students to assume autonomy in their own critical reflections that foster critical pedagogy.

\section{Conclusion}

The authors of this reflective essay have recalled three classroom activities and showcased how Black Gen- $Z$ students from an HBCU could relate to and take inspiration from community leaders' speeches, detect and trace misinformation about COVID-19 and other topical issues, and use public narrative as a tool for speaking out on social change. The data show that through the activities, students honed their skills in critical thinking and saw the positive impact of role models and leaders. HBCU students may not have encountered institutionalized racism at an HBCU campus as their peers do at predominately White institutions. However, they witness societal problems daily. Previous research has indicated that African American college students feel concerned about racial issues and the future of the country, and they largely disagree with what President Trump had done to deepen the wounds of the racial divide (Sun, 2021; Sun et al., 2019). The classroom can be utilized to cultivate a keen awareness of misinformation and social inequality and empower future generations to be critical thinkers. With the current college students being largely members of Gen Z, the digital-native generation that consumes so much information, critical media literacy and the ability to identify and navigate reports about social issues and the state of the world around them are a pertinent goal in education and social justice.

\section{References}

Alvermann, D. Moon, J. S., \& Hagood, M. C. (2017). Popular culture in the classroom: Teaching and researching critical media literacy. Routledge.

Bassett, M. M., Martinez, J., \& Martin, E. P. (2014). Self-directed activity-based learning and achievement in high school chemistry. Education Research and Perspectives, 41, 73-94.

Bode, L., \& Vraga, E. K. (2017). See something, say something: Correction of global health misinformation on social media. Health Communication, 33(9), 1131-1140. https://doi.org/10.1080/10410236.2017.1331312

Biden, D. (2014). Look on the bright side: A comparison of positive and negative role models in business ethics education. Academy of Management Learning \& Education. 13(2). https://doi.org/10.5465/amle.2012.0251

Byrnes, J. P. (2001). Minds, brains, and learning: Understanding the psychological and educational relevance of neuroscientific research. Guildford Press.

Camfield, E. K., Moore, J. L., \& Allen, J. (2020). Sifting through Gen Z stereotypes: Using critical empathy to assess writers' invisible learning. Journal of Higher Education Theory and Practice, 20(6), 121-131.

Journal of the Scholarship of Teaching and Learning, Vol. 21, No. 4, December 2021. josotl.indiana.edu 
Chou, W.-Y. S., Oh, A., \& Klein, W. M. P. (2018). Addressing health-related misinformation on social media. JAMA, 320(23), 2417-2418. https://doi.org/10.1001/jama.2018.16865

City Scrollz. (2020, February 17). Chinese doctors confirmed African blood genetic composition resist coronavirus after student cured. Archive.is. https://archive.is/sKtDE

Coulter, C., Michael, C., \& Poynor, L. (2007). Storytelling as pedagogy: An unexpected outcome of narrative inquiry. Curriculum Inquiry, 37(2), 103-122.

Darling-Hammond, L. (2017). Teaching for social justice: Resources, relationships, and anti-racist practice. Multicultural Perspectives, 19(3), 133-138. https://doi.org/10.1080/15210960.2017.1335039

Dessem, M. (2020, May 31). Police erupt in violence nationwide. Slate Magazine. https://slate.com/news-and-politics/2020/05/george-floyd-protests-police-violence.html

Dukes, K. N., \& Gaither, S. E. (2017). Black racial stereotypes and victim blaming: Implications for media coverage and criminal proceedings in cases of police violence against racial and ethnic minorities. Journal of Social Issues, 73(4), 789-807. https://doi.org/10.1111/josi.12248

Espinosa, M. (2014). The question of racial immunity to yellow fever in history and historiography. Social Science History, 38(3-4), 437-453. https://doi.org/10.1017/ssh.2015.20

Forsman, M. (2020). Media literacy and the emerging media citizen in the Nordic media welfare state. Nordic Journal of Media Studies, 2(1), 59-70. https://doi.org/10.2478/njms-2020-0006

Frechette, J. D. (2002). Developing media literacy in cyberspace: Pedagogy and critical learning for the twenty-first century classrooms. Praeger Publishers.

Freire, P. (1970). Pedagogy of the oppressed. Bloomsbury Academic.

Freire, P. (1998). Politics and education. UCLA Latin American Center Publications.

Fridkin, K., Wintersieck, A., Courey, J., \& Thompson, J. (2017). Race and police brutality: The importance of media framing. International Journal of Communication, 11, 3394-3414.

Fung, I. C.-H., Fu, K.-W., Chan, C.-H., Chan, B. S. B., Cheung, C.-N., Abraham, T., \& Tse, Z. T. H. (2016). Social media's initial reaction to information and misinformation on Ebola, August 2014: Facts and rumors. Public Health Reports, 131(3), 461-473. https://doi.org/10.1177/003335491613100312

Funk, S., Kellner, D., \& Share, J. (2016). Critical media literacy as transformative pedagogy. In Handbook of research on media literacy in the digital age (pp. 1-30). IGI Global.

Gainer, J. S. (2010). Critical media literacy in middle school: Exploring the politics of representation. Journal of Adolescent \& Adult Literay, 53(5), 364-373. https://doi.org/10.1598/jaal.53.5.2

Ganz, M. (2010) Leading change: Leadership, organisation and social movements. In N. Nohria \& R. Khurana (Eds.), Handbook of leadership theory and practice (pp. 509-550). Harvard Business School Press.

Ganz, M., \& McKenna, E. (2018). Bringing leadership back in. In The Wiley Blackwell Companion to Social Movements (pp.185-202). Blackwell Publishing.

Garcia, A., Seglem, R., \& Share, J. (2013). Transforming teaching and learning through critical media literacy pedagogy. Learning Landscapes, 6(2), 109-124.

Golden, J. N. (2020, April 7). Black people are not immune to coronavirus: Debunking deadly social media myths. Block Club Chicago. https://blockclubchicago.org/2020/04/07/black-people-arenot-immune-to-coronavirus-debunking-deadly-social-media-myths/

Golden, S. H. (2020, April 20). Coronavirus in African Americans and other people of color. Johns Hopkins Medicine. https://www.hopkinsmedicine.org/health/conditions-anddiseases/coronavirus/covid19-racial-disparities

Gunn, J. (2018). Speech craft. Bedford/St. Martin's. 
Happer, C., \& Philo, G. (2013). The role of the media in the construction of public belief and social change. Journal of Social and Political Psychology, 1(1), 321-336. https://doi.org/10.5964/jspp.v1i1.96

Hardcastle, V. G. (2003). The development of the self. In G. D. Fireman, T. E. McVay, \& O. J. Flanagan (Eds.), Narrative and consciousness: Literature, psychology and the brain (pp. 37-50). Oxford University Press.

Harris, J. (2019). Fighting social normalization in Generation Z: Trans* youth activism on Tumblr. Media and Gender. 3(1). https://doi.org/10.29311/for(e)dialogue.v3i1.3145

Hobbs, R. (2012). Digital and media literacy: Connecting culture and classroom. Hawker Brownlow Education.

Hogarth, R. A. (2019). The myth of innate racial differences between White and Black people's bodies: Lessons from the 1793 yellow fever epidemic in Philadelphia, Pennsylvania. American Journal of Public Health, 109(10), 1339-1341. https://doi.org/10.2105/ajph.2019.305245

Howell, P. B., Cantrell, S. C., \& Rintamaa, M. (2019). Setting the stage for action: Teaching social justice in the middle school classroom. The Clearing House: A Journal of Educational Strategies, Issues and Ideas, 92(6), 185-192. https://doi.org/10.1080/00098655.2019.1649630

Huchting, K., \& Stephenson, R. (2021). Implementing social justice practices online: Lessons learned from teaching and advising dissertations in practice during the COVID-19 pandemic. Impacting Education: Journal on Transforming Professional Practice, 6(2), 34-38. https://doi.org/10.5195/ie.2021.168

Hussain, S., Anwar, S., \& Majoka, M. I. (2011). Effect of peer group activity-based learning on students' academic achievement in physics at secondary level. International Journal of Academic Research, 3(1).

Jack, K., Hamshire, C., and Chambers, A. (2017). The influence of role models in undergraduate nurse education. Journal of Clinical Nursing.https:doi.org/10.111/jocn.13822

Jackson, S. J. (2020, June 3). The headlines that are covering up police violence. The Atlantic. https://www.theatlantic.com/culture/archive/2020/06/george-floyd-protests-what-newsreports-dont-say/612571/

Juris, J. S. (2005). Violence performed and imagined. Critique of Anthropology, 25(4), 413-432. https://doi.org/10.1177/0308275x05058657

Kanpol, B. (1999). Critical pedagogy: An introduction. Bergin \& Garvey.

Karunanayake, D. and Nauta, M. (2004). The relationship between race and students' identified career role models and perceived role model influence. The Career Development Quarterly. 52(3):225-234. DOI: 10.1002/j.2161-0045.2004.tb00644.x

Kellner, D. (1995). Media communications vs. cultural studies: overcoming the divide. Communication Theory, 5(2), 162-177. https://doi.org/10.1111/j.1468-2885.1995.tb00104.x

Kellner, D., \& Share, J. (2005). Toward critical media literacy: Core concepts, debates, organizations, and policy. Discourse: Studies in the Cultural Politics of Education, 26(3), 369-386. https://doi.org/10.1080/01596300500200169

Kellner, D., \& Share, J. (2007). Critical media literacy: Crucial policy choices for a twenty-firstcentury democracy. Policy Futures in Education, 5(1), 59-69. https://doi.org/10.2304/pfie.2007.5.1.59

Kelly, R. (March 11, 2021). 6 ways COVID-19 and social justice intersect in higher ed. Campus Technology. https://campustechnology.com/articles/2021/03/11/6-ways-covid-19-andsocial-justice-intersect-in-higher-ed.aspx

Kilgo, D. K. (2020, June 2). George Floyd killing: How reporting bias and sensationalism shape protest coverage. Scroll.in. https:// scroll.in/article/963491/george-floyd-killing-how-reporting-bias-andsensationalism-shape-protest-coverage

Journal of the Scholarship of Teaching and Learning, Vol. 21, No. 4, December 2021. josotl.indiana.edu 
Maqbool, A. (2020, April 11). Why are African Americans hit so hard by virus? BBC News. https://www.bbc.com/news/world-us-canada-52245690

McLernon, L. M. (2021, February 9). Experts seek to allay covid vaccine hesitancy in Black Americans. CIDRAP. https://www.cidrap.umn.edu/news-perspective/2021/02/experts-seek-allaycovid-vaccine-hesitancy-black-americans

Moorhead, S. A., Hazlett, D. E., Harrison, L., Carroll, J. K., Irwin, A., \& Hoving, C. (2013). A new dimension of health care: Systematic review of the uses, benefits, and limitations of social media for health communication. Journal of Medical Internet Research, 15(4), Article e85. https://doi.org/10.2196/jmir.1933

Moran, P. (2020). Social media: A pandemic of misinformation. The American Journal of Medicine, 133(11), 1247-1248. https://doi.org/10.1016/j.amjmed.2020.05.021

Natty, G. H. (2020, February 12). Break positive news: Cameroonian student survives coronavirus because of his blood composition. GhGossip. https://www.ghgossip.com/breaking-positive-newscameroonian-student-survives-coronavirus-because-of-his-blood-composition/

Nelson, T. E., \& Oxley, Z. M. (1999). Issue framing effects on belief importance and opinion. The Journal of Politics, 61(4), 1040-1067. https://doi.org/10.2307/2647553

O’Byrne, W. I. (2013). Online content construction: Empowering students as readers and writers of online information. In K. E. Pytash \& R. E. Ferdig (Eds.), Exploring technology for writing instruction (pp. 213-231). IGI Global Publishing.

Oyeyemi, S. O., Gabarron, E., \& Wynn, R. (2014). Ebola, Twitter, and misinformation: A dangerous combination? BMJ, 349, Article g6178. https://doi.org/10.1136/bmj.g6178

Pang, K. (2010). Creating stimulating learning and thinking using new models of activity-based learning and metacognitive-based activities. Journal of College Teaching \& Learning, 7(4), 29-38. https://doi.org/10.19030/tlc.v7i4.112

Phillips, L. (2013). Storytelling as pedagogy. Literacy Learning: The Middle Years, 21(2), ii-iv.

Pierre-Louis, K. (2020, June 24). It's time to change the way the media reports on protests. Here are some ideas. Nieman Lab. https://www.niemanlab.org/2020/06/its-time-to-change-the-way-the-mediareports-on-protests-here-are-some-ideas/

Reyes, G., \& Sander, S. A. (2019). Tensions between urgency and scaffolding students into social justice education. Curriculum \& Teaching Dialogue, 21(1/2), 123-126.

Ross, J. (2020). Coronavirus outbreak revives dangerous race myths and psendoscience. NBC News. https://www.nbcnews.com/news/nbcblk/coronavirus-outbreak-revives-dangerous-racemyths-pseudoscience-n1162326

Savage, R., Chen, K., \& Vanasupa, L. (2009). Integrating project-based learning throughout the undergraduate engineering curriculum. IEEE Engineering Management Review, 37(1), 25-25. https://doi.org/10.1109/emr.2009.4804346

Seemiller, C., \& Grace, M. (2016). Generation Z goes to college. Jossey-Bass.

Seemiller, C., \& Grace, M. (2017). Generation Z: Educating and engaging the next generation of students. About Campus: Enriching the Student Learning Experience, 22(3), 21-26.

Seemiller, C., Grace, M., Campagnolo, P., Alves, I., \& Borba, G. (2019). How Generation Z college students prefer to learn: A comparison of U.S and Brazil Students. Journal of Educational Research \& Practice, 9(1). https://doi.org/10.5590/JERAP.2019.09.1.25

Seemiller, C., \& Smith, C. (2019). Developing the strengths of Generation Z college students. Journal of College and Character, 20(3), 268-275. https://doi.org/10.1080/2194587X.2019.1631187

Sun, W. (2021). HBCU undergraduate students perceived stress management and coping skills. Qualitative Research Reports in Communication. https://doi.org/10.1080/17459435.2020.1871402

Journal of the Scholarship of Teaching and Learning, Vol. 21, No. 4, December 2021. josotl.indiana.edu 
Sun, W., Herbert, S., \& Jenkins, J. (2019). College millennials' career preparedness to the workforce: They say they are ready. In S. Smith (Ed.), Recruitment, retention, and engagement of a Millennial workforce (pp. 15-35). Lexington Books.

Torres, M., \& Mercado, M. (2006). The need for critical media literacy in teacher education core curricula. Educational Studies, 39(3), 260-282. https://doi.org/10.1207/s15326993es3903 5

Watkins, S. C. (2001). Framing protest: News media frames of the million-man march. Critical Studies in Media Communication, 18(1), 83-101. https://doi.org/10.1080/15295030109367125

Welton, A. D., \& Freelon, R. (2018). Community organizing as educational leadership: Lessons from Chicago on the politics of racial justice. Journal of Research on Leadership Education, 13(1), 79104. https://doi.org/10.1177/1942775117744193

Wikipedia. (n.d.). Category: Articles with peacock terms. Wikipedia. https://en.wikipedia.org/wiki/Category:Articles with peacock terms

Working Narratives. (n.d.). What is public narrative and how can we use it? https://workingnarratives.org/article/public-narrative/

Yeung, D. (2018). Social media as a catalyst for policy action and social change for health and wellbeing: Viewpoint. Journal of Medical Internet Research, 20(3), Article e94. https://doi.org/10.2196/jmir.8508 